\title{
EDITORIAL
}

\section{Classes of evidence in neurosurgery}

\author{
James T. Rutka, MD, PhD \\ Editor-in-Chief, Journal of Neurosurgery Publishing Group, Charlottesville, Virginia
}

$\mathrm{W}$ E have all witnessed the increasing application of evidence-based medicine (EBM) practices in our hospitals, at our meetings, and in our journals. EBM relies on the hierarchical classification of evidence. Interestingly, the Canadian Task Force on Periodic Health Examination was the first to report on levels of evidence. ${ }^{4}$ Since that publication, other classification systems have emerged, ${ }^{3,7}$ with the most widely adopted one distinguishing 5 different levels of evidence (Table 1). In this classification system, randomized clinical trials (RCTs) and meta-analyses of randomized trials with homogeneous results have the highest level of evidence (Level I) and case reports, expert opinion, and personal observations having the lowest (Level V) (Table 1).

The designation of the various levels of evidence will also depend on whether the studies are therapeutic, prognostic, or diagnostic. Adjectives can also be used to describe evidence-based practice recommendations whereby "strong" applies to Class I evidence; "moderate" to Class II or III evidence, or Class I evidence from a single study; and "weak" to Class IV or V evidence from more than 1 study, or Class II or III evidence from a single study. ${ }^{1,2}$

\section{TABLE 1. Different levels of evidence}

\begin{tabular}{cl}
\hline $\begin{array}{c}\text { Evidence } \\
\text { Level }\end{array}$ & \multicolumn{1}{c}{ Description } \\
\hline I & $\begin{array}{c}\text { 1) Randomized controlled trial (RCT); 2) meta-analysis of } \\
\text { randomized trials w/ homogeneous results }\end{array}$ \\
\hline II & $\begin{array}{l}\text { 1) Prospective comparative study (therapeutic); 2) meta- } \\
\text { analysis of Level II studies or Level I studies w/ incon- } \\
\text { sistent results }\end{array}$ \\
\hline III & $\begin{array}{l}\text { 1) Retrospective cohort study; 2) case-control study; } \\
\text { 3) meta-analysis of Level III studies }\end{array}$ \\
\hline IV & 1) Case series \\
\hline V & 1) Case report; 2) expert opinion; 3) personal observation \\
\hline
\end{tabular}

In this issue of the Journal of Neurosurgery, we introduce the classification of levels of evidence within select clinical research articles., ${ }^{5,6,8}$ The designation of the level of evidence for each article is based on the data provided within the manuscript, and an analysis performed by Dr. Michael Glantz, Professor of Neurosurgery, Medicine, and Neurology at Penn State Hershey, who has had a longstanding interest in teaching statistics and statistical methods to neurosurgeons at our national meetings. Periodically, Dr. Glantz will review clinical research articles for the Journal and ascribe a level of evidence to each.

Articles in which levels of evidence are provided will be easy to identify within each issue by virtue of a new icon, a pyramid, that will be found alongside the title (Fig. 1).

This icon was selected as the most prominent figure used to depict levels of evidence in online searches. For the purposes of the Journal, classification of evidence will be found beneath the Abstract of select articles; and a detailed analysis of how the level of evidence was determined in each case will be provided in a shaded text box on a subsequent page.

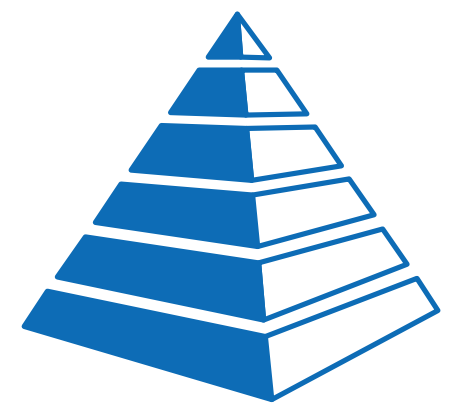

FIG. 1. Classification of evidence icon. Figure is available in color online only. 
These days, many journals are providing a synopsis of levels of evidence for clinical research studies that are published. Please be assured that authors will be provided with the classification of evidence and the synopsis of level of evidence of their work prior to publication. Authors may choose whether or not they wish to have this commentary published within the body of their research work. I do hope you will all be alert to the "pyramid icon" as you are reading articles within the Journal and will find such descriptions and analyses of levels of evidence both informative and timely.

https://thejns.org/doi/abs/10.3171/2016.4.JNS161067

\section{References}

1. Bhandari M, Buyatt GH, Swiontkowski MF: User's guides to the orthopaedic literature: how to use an article about prognosis. J Bone Joint Surg Am 83-A:1555-1564, 2001

2. Bhandari M, Richards RR, Spraque S, Schemitsch EH: The quality and reporting of randomized trials in the Journal of Bone and Joint Surgery from 1988 through 2000. J Bone Joint Surg Am 84-A:388-396, 2002

3. Burns PB, Rohrich RJ, Chung KC: The levels of evidence and their role in evidence-based medicine. Plast Reconstr Surg 128:305-310, 2011

4. Canadian Task Force on the Periodic Health Examination: The periodic health examination. Can Med Assoc J 121:1193-1254, 1979 (Erratum in Can Med Assoc J 122:163, 1980)

5. Garcia MA, Lazar A, Duriseti S, Raleigh DR, Hess CP, Fogh SE, et al: Discovery of additional brain metastases on the day of stereotactic radiosurgery: risk factors and outcomes. J Neurosurg [epub ahead of print July 1, 2016. DOI: 10.3171/2016.4.JNS152319]

6. Raleigh DR, Seymour ZA, Tomlin B, Theodosopoulos PV, Berger MS, Aghi MK, et al: Resection and brain brachytherapy with permanent iodine-125 sources for brain metastasis. J Neurosurg [epub ahead of print July 1, 2016. DOI: 10.3171/2016.4.JNS152530]

7. Sackett DL: Rules of evidence and clinical recommendations on the use of antithrombotic agents. Chest 95 (2 Suppl):2S4S, 1989

8. Zhao B, Yang H, Zheng K, Li Z, Xiong Y, Tan X, et al: Preoperative and postoperative predictors of long-term outcome after endovascular treatment of poor-grade aneurysmal subarachnoid hemorrhage. J Neurosurg [epub ahead of print July 1, 2016. DOI: 10.3171/2016.4.JNS152587] 